\title{
Landslides Hazard Mapping in Rwanda using Bivariate Statistical Index Method
}

\author{
Lamek Nahayo ${ }^{a, b, c, d, e}$, Christophe Mupenzi ${ }^{e}$, Gabriel Habiyaremye ${ }^{f}$, Egide Kalisa ${ }^{g}$, \\ Madeleine Udahogora ${ }^{d}$, Vincent Nzabarinda ${ }^{a, d}$ and Lanhai Li $^{a, b, c^{*}}$ \\ *Corresponding Author. E-mail: lilh@ms.xjb.ac.cn

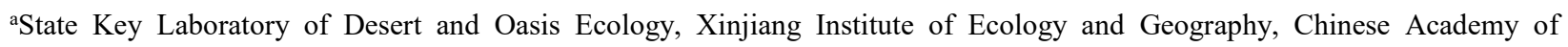 \\ Sciences, 818 South Beijing Road, Urumqi, Xinjiang, 830011, China \\ 'Ili Station for Watershed Ecosystem Research, Urumqi, 830011, Xinjiang, China \\ ${ }^{\mathrm{c}}$ CAS Research Center for Ecology and Environment in Central Asia, Urumqi, 830011, Xinjiang China \\ dUniversity of Chinese Academy of Sciences, Beijing 100049, China \\ eUniversity of Lay Adventists of Kigali, P. O. Box 6392, Kigali-Rwanda \\ fLancaster Environmental Center, Library Avenue, Lancaster University, Lancaster LA1 4YQ, United Kingdom

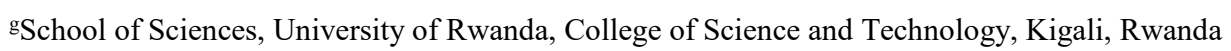

\begin{abstract}
Landslides hazard mapping (LHM) is essential in delineating hazard prone areas and optimizing low cost mitigation measures. This study applied the Geographic Information System (GIS) and statistical index (SI) method in landslides hazard mapping in Rwanda. Field surveys identified 336 points which were employed to construct a landslides inventory map. Ten landslides predicting factors: normalized difference vegetation index, elevation, slope, aspects, lithology, soil texture, distance to rivers, distance to roads, rainfall, and land use were analyzed. The factor variables were converted into categorized variables according to the percentile divisions of seed cells. Then values of each factor's class weight were calculated and summed to create landslides hazard map. The estimated hazard map was split into five hazard classes (very low, low, moderate, high and very high). The results indicated that the northern, western and southern provinces are largely exposed to landslides hazard. The major landslides hazard influencing factors are elevation, slope, rainfall and poor land management. Overall, this landslides hazard mapping would help policy makers to recognize each area's hazard extent, key triggering factors and the required hazard mitigation measures. These measures include planting trees to enhance vegetation cover and reduce the runoff, and construction of buildings on low steep slope areas to reduce people's hazard exposure; while agroforestry and bench terraces would reduce sediments which take out the exposed soil (erosion) and pollute water quality.
\end{abstract}


Keywords: Hazard; Landslides; Geographic Information System; Rwanda.

\section{Introduction}

Landslides are among the global widespread geological hazards responsible for considerable human injury and death, natural resources degradation, infrastructure damage, and loss of cultural and natural heritage (Lian et al. 2014; Riedel et al. 2010). The term landslide describes a wide range of processes responsible for downward and outward movement of slope forming material composed of rock, soil, artificial fills or a combination of all these down a slope (Fey et al. 2015; Fan et al. 2018; Lee et al. 2015; Capitani et al. 2013). Landslides occurrence depends on intrinsic and extrinsic variables. Intrinsic variables include soil depth and soil type, slope aspects and slope curvature, elevation, vegetation cover and other anthropogenic activities such as deforestation, road construction and cultivation on steep slope which change the land cover and land use patterns then inversely impact on mass movement process. The extrinsic variables include extreme rainfall, earthquake and volcanic activities (Yiping et al. 2014; Zhu et al. 2007; Kelman 2017; Kannan et al. 2013; Van Westen et al. 2008).

Hazard is the probability of occurrence of a particular damaging phenomenon, within a specified period of time and a given area due to different existing or predicted conditions (Kim et al. 2018; Riedel et al. 2010). The unprotected land increases the slope instability which causes soil erosion, mudslides and landslides, and pollutes water quality by the loaded wastes (Xu et al. 2018). Thus, landslides hazard mapping can help to identify the hazard level and areas that are susceptible to soil loss and water quality pollution. The process also indicates safe zones for human constructions and other social, economic and environmental activities, and strengthens the mitigation and adaptation to future occurrence (Naidu et al. 2017; Reis et al. 2009; Jaafari et al. 2015). Hazard mapping can be broadly divided into: (1) direct hazard mapping, where the degree of hazard is determined by the knowledge of the terrain conditions and (2) indirect hazard mapping in which either statistical or deterministic models are used to predict landslides prone areas based on triggering factors. The latter is the most commonly applied due to its advantage of describing the functional relationship between factors, and the past, present and the predicted distribution of slope failures (Dou et al. 2015; Di et al. 2017; Lei et al. 2014; Bobrowsky and Highland 2013; Tian et al. 2017; Frodella et al. 2018; Micheletti et al. 2014; Fey et al. 2015). 
Different indirect approaches including not limited to bivariate and multivariate method, fuzzy logic and artificial neural networks, analytical hierarchy process, evidential belief function, support vector machine, random forest and logistic regression have been used for landslides hazard mapping (Nichol et al. 2006; Shi-Biao et al. 2009; Kazakis et al. 2015; Hong et al. 2016; Kim et al. 2010; Banerjee et al. 2018; Sharma et al. 2014; Lian et al. 2014). In Rwanda, previous disaster related studies (Nahayo et al. 2017; Piller 2016; MIDIMAR 2014; Nduwayezu et al. 2015) were general combining different hazards like flood and landslides, drought and flood, without specific attention attributed to one hazard. These studies have only considered the hazards already occurred by using descriptive, secondary data sources and social approaches, and were limited to case studies like districts and provinces. This expresses lack of a thorough analysis to indicate the root causes of the considered hazard for the adaption and exposure reduction countrywide. Thus, this study considers the whole Rwandan territory and applies GISbased statistical index method in landslides hazard mapping.

The bivariate statistical index method is selected among others due to its advantage that in case landslides inventories are available, hazard assessment integrates knowledge from the overlap of observed incidents and maps of different triggering factors (Van Westen et al. 1997). Also, its validation proves its performance effectiveness as it bases on the fitness between the produced landslides hazard and observed landslides. This as a result, gives extensive knowledge of the location and landslides causal factors, extent of community hazard exposure, future occurrence likelihood, and potential exposure hotspots for sustainable planning and prevention of future losses (Van Westen et al. 2008; Van Westen et al. 1997). As a new attempt in landslides hazard mapping countrywide, the authors chose to use the bivariate statistical index method to test its performance in landslides hazard mapping regardless of the strengths and/or weaknesses of other approaches mentioned above. In the future, authors plan to test the effectiveness of other landslides hazard mapping approaches in this area.

\section{Materials and Methods}

\subsection{Study Area}

Rwanda is a poor and densely populated East African country with a green and mountainous landscape. The country (Fig.1 (a)) is bordered by the Democratic Republic of Congo in the west, 
Uganda in the north, Burundi in the south and Tanzania in the east. The country records rainfall between March and May and from late September to early December. The average monthly rainfall is about 110-200 mm. The dry season occurs from late December to the end of February, and between June and early September. The average temperature ranges between 19 to $27^{\circ} \mathrm{C}$ (Nsengiyumva et al. 2018). In this area, high annual rainfall intensity and population pressure on land expose the hilly topographic nature to runoff risks. This causes severe environmental disasters and encroachment on fragile ecosystems. Among which landslides and floods are the frequently recorded (Piller 2016; Nduwayezu et al. 2015; Nsengiyumva et al. 2018).

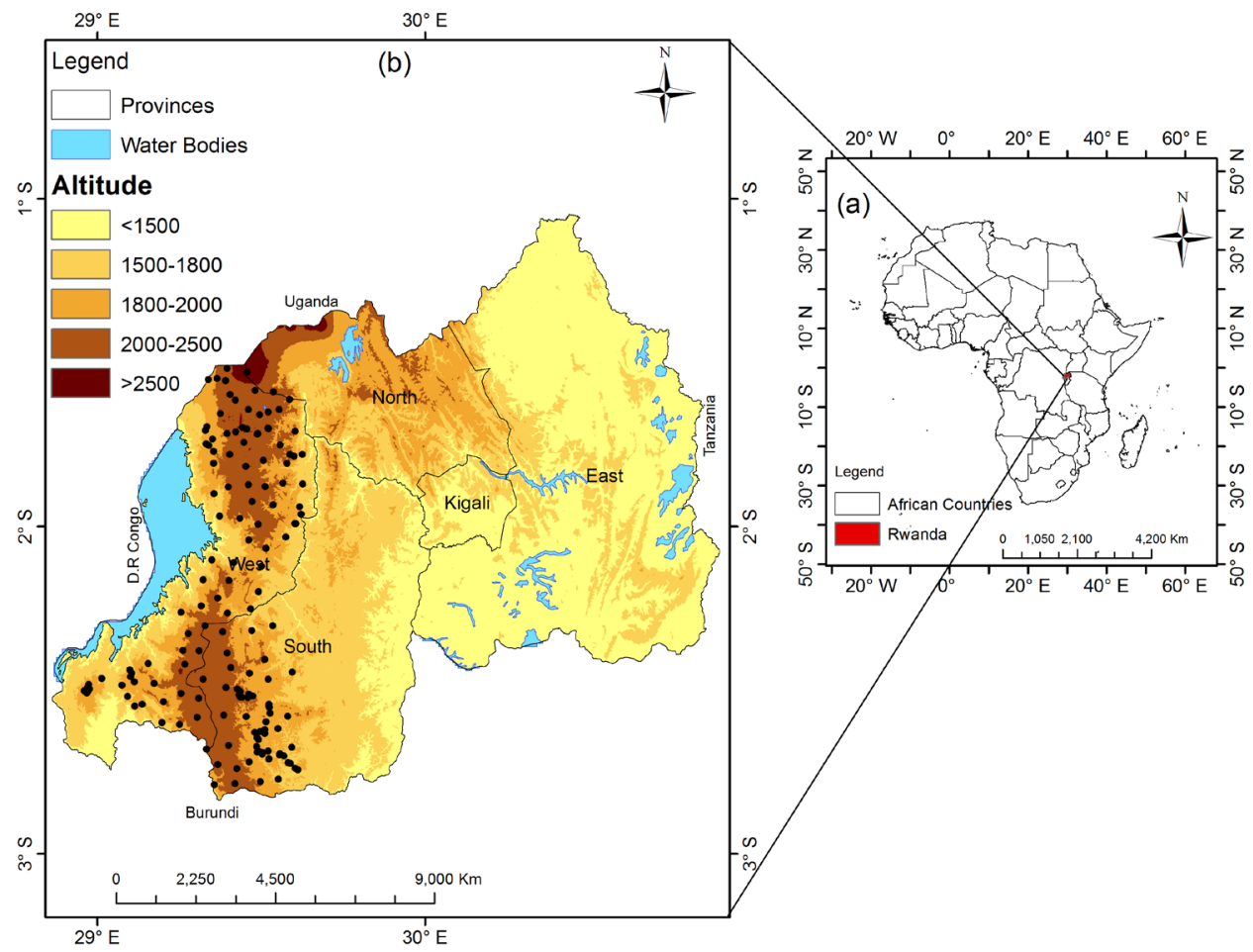

Figure 1 Geographical location of (a) Rwanda in Africa and (b) its landslides inventory

\subsection{Datasets}

\subsubsection{Landslides inventory}

Landslides inventory map, also known as landslides map, landslides inventory or inventory map records the location, date of occurrence and types of movements that have left noticeable traces in the area (Guzzetti et al. 2012). This can be prepared by different techniques and the selection of the techniques to employ relies on the purpose of the inventory, scale of the base maps and 
extent of the study area, and available resources (Alvioli et al. 2018; Van Westen et al. 2008). For landslides hazard assessment, the report of Van Westen et al., (2008) suggested to take into account the fact that, the conditions that led to past landslides in the area of study if reoccurred may result from the same causative factors. Hence, authors recognized the assumption and for this study, a total of 336 landslides were identified by using the Global Positioning Systems (GPS) during field surveys facilitated by local residents who helped to localize last landslides events in their living areas. The produced landslides inventory map (Fig.1 (b)) considered landslides occurrence and frequency based on the affected people (killed, injured and homeless), cropland damaged, destroyed infrastructures and livestock lost between 2000 and 2017 in Rwanda.

\subsubsection{Landslides hazard triggering factors}

The authors selected landslides hazard influencing factors in Rwanda based on the review of the literature and field observation (Fig.1 (b)). Also, national disaster risk management policy, and contingency plan for flood and landslides in Rwanda (MIDIMAR 2014) along with the landslides hazard and risk assessment of the United Nations International Strategy for Disaster Reduction (UNISDR, 2017) were used as experts' opinions. The terrain attributes like slope, slope aspects, curvature and elevation which represent spatial variation of elevation (i.e., altitude or height) are the most substantial causes of landslides. Their higher values express high likelihood of landslides occurrence (Jaafari et al. 2015; Frodella et al. 2018; Riedel et al. 2010). For this study, the employed elevation, slope and aspects (Fig.2) were derived from Digital Elevation Model (DEM) of $30 \mathrm{~m}$ resolution acquired from the United States Geological Survey Earth Explorer (USGS 2018). 


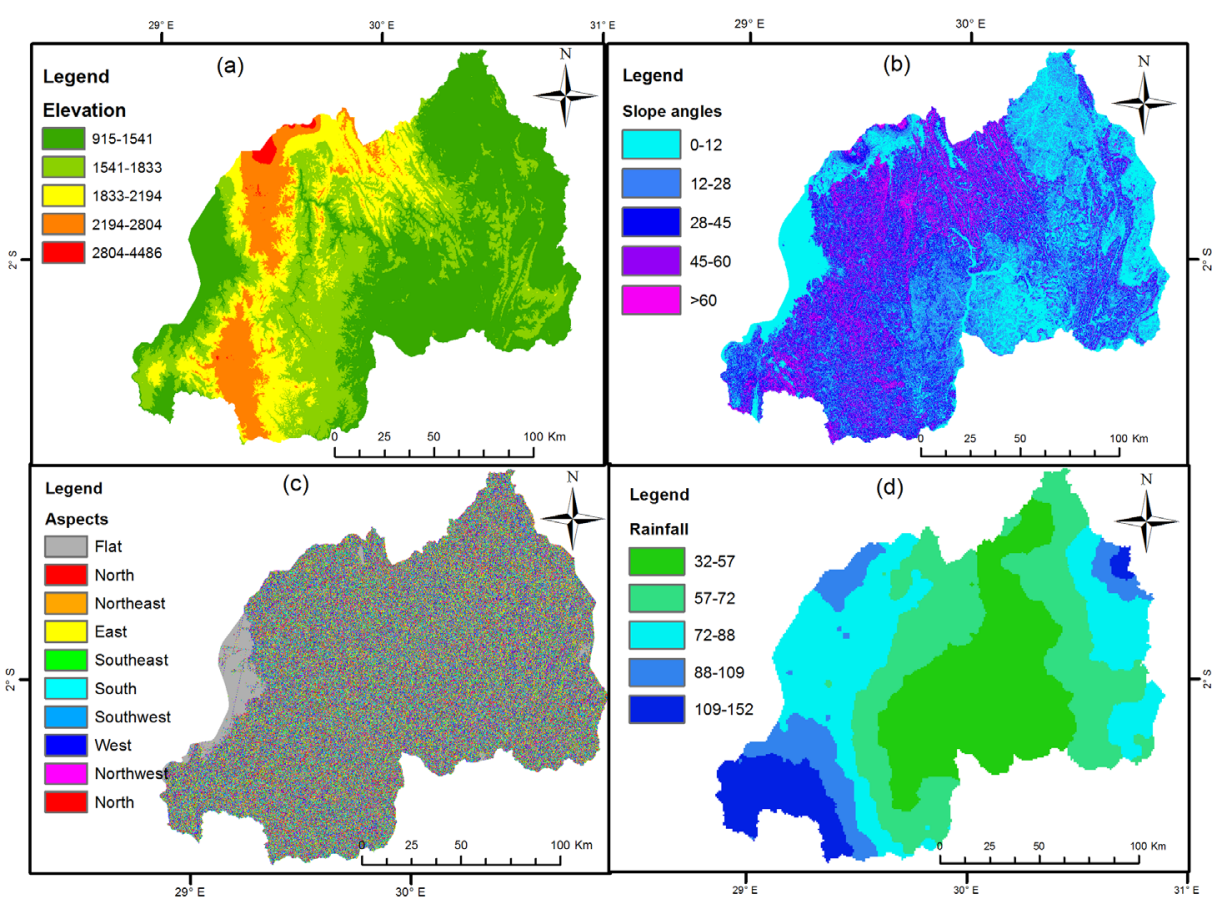

Figure 2. Selected landslides hazard conditioning factors in Rwanda: (a) elevation, (b) slope, (c) aspects and (d) rainfall

Rainfall-induced landslides are highly recorded within mountainous regions (Alvioli et al. 2018). Similarly, more than $70 \%$ of landslides recorded in Rwanda are rainfall-induced (MIDIMAR 2014). Authors recognized this fact, and then added rainfall among the employed datasets. The mean monthly rainfall data (Fig.2 (d)) were interpolated using 27 years (1990-2017) rainfall data acquired from meteorological stations located in Rwanda. The used rainfall data were provided by the Rwanda Meteorology Agency (RMA 2018). Each rock and soil class influences the type and intensity of landslides. Therefore, their classification would help to demonstrate each class's contribution (Mertens et al. 2018). The lithological and geological features employed by this study (Fig.3) were derived from the geological, mining and soil map databases of Rwanda (Rushemuka et al. 2014). The distance to roads were added among the datasets (Fig.3) of the current study due to the fact that, cutting of slopes for roads construction or road widening in hilly regions can cause slope failures and lead to landslides losses among the exposed nearby populations (Dou et al. 2015). The distance to rivers was used (Fig.3) based on the fact that the proximity to rivers increases the likelihood of landslides occurrence because the slopes on the banks of the river often suffer river erosion. Thus, at a closer distance to rivers, the probability of landslides occurrence is high due to strong erosion (Cao et al. 2016; Fan et al. 2017). The 
shapefiles of rivers and roads were acquired from an online database (http://www.divagis.org/gdata), and both were produced by creating Euclidean distance in ArcMap-Spatial Analyst extension.

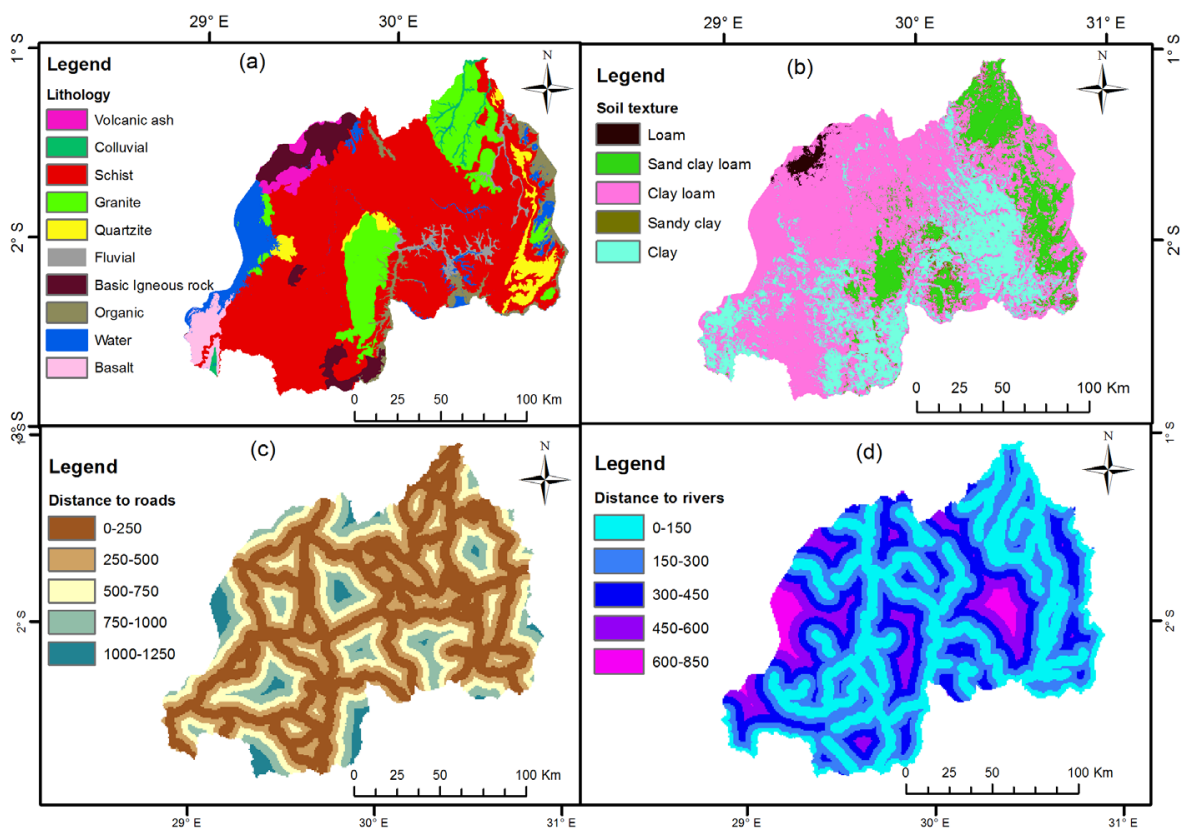

Figure 3. Selected landslides hazard conditioning factors in Rwanda: (a) lithology and (b) soil texture classes, and (c) distance to roads and (d) distance to rivers

Rwanda's update land use and land cover map of July 2018 was produced form multispectral Landsat-8 Operational Land Imager (OLI) images. These images were acquired from the United States Geological Survey Earth Explorer (USGS 2018). The land use/cover map was classified with the supervised maximum classification method based on the East African Classification of the Regional Center for Mapping of Resources for Development (RCMRD 2018). Then five land use and land cover classes (Fig.4 (a)) were produced. The normalized difference vegetation index (NDVI) reveals the presence or absence of vegetation in a given area. Thus, the removal of vegetation leaves a slope much more exposed to surficial landslides due to the loss of the stabilizing root systems (Ibrahim et al. 2015; Xu et al. 2018). For this study, the used NDVI (Fig.4 (b)) was acquired from Moderate Resolution Imaging Spectroradiometer (MODIS, 250M resolution) downloaded from an online database (ladsweb.nasacom.nasa.gov/data/html). The NDVI values were calculation based on the following equation: 
$\mathrm{NDVI}=\frac{I R-R}{I R+R}$

Where IR is the infrared portion of electromagnetic spectrum and $\mathrm{R}$ value is the red portion of electromagnetic spectrum.

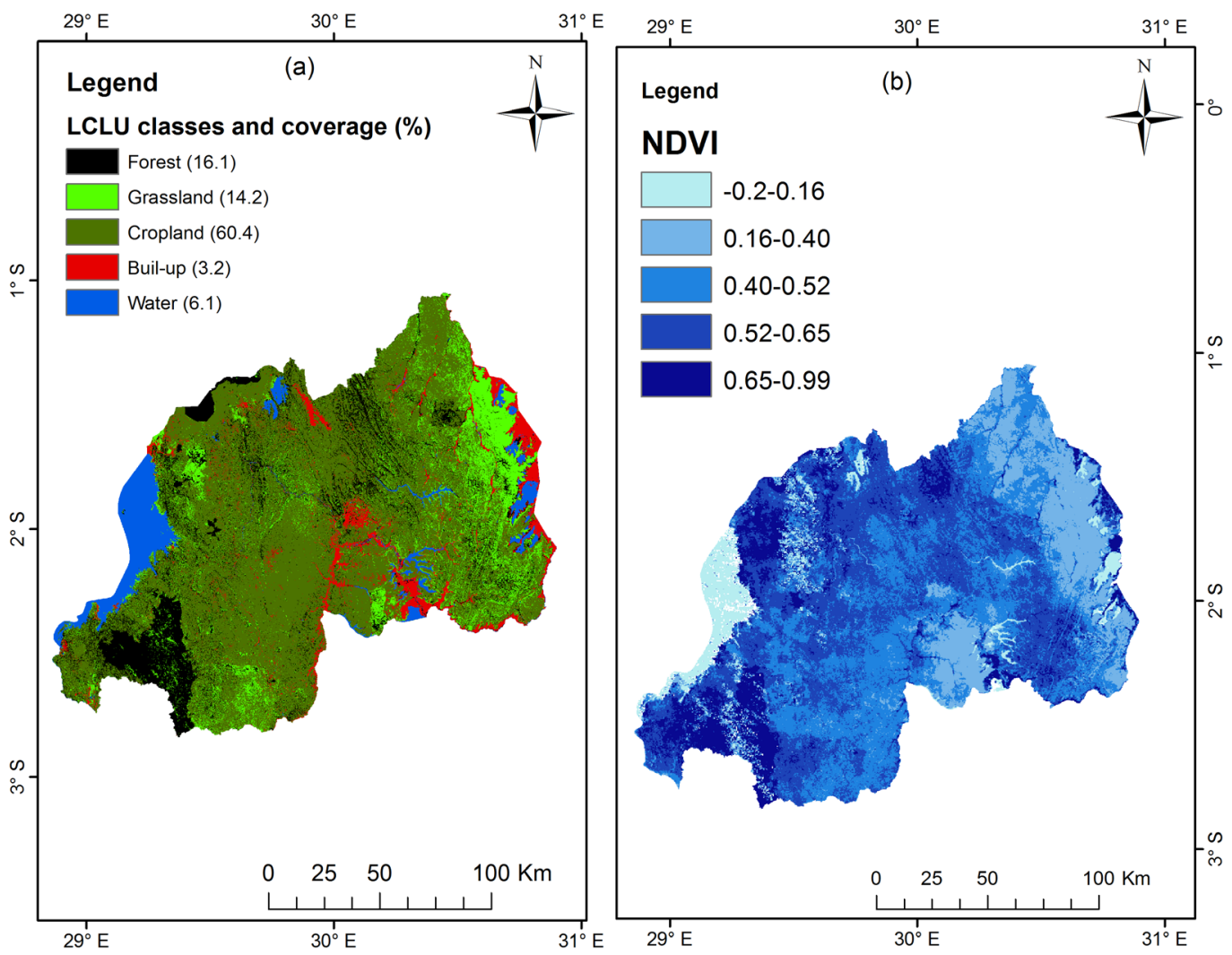

Figure 4. Selected landslides hazard conditioning factors in Rwanda: (a) land use and land cover classes and coverage in percentage and (b) Normalized Difference Vegetation index values

\subsection{Methodology}

\subsubsection{Modeling approach}

Authors applied the Statistical Index (SI) model accepted as bivariate statistical method (Van Westen et al. 1997). The model has a basis requiring calibration from correlation between known incidents. In the model, the weighting value for each conditioning factor class is defined as the natural logarithm of the landslides density in a class divided by landslides density in the entire map (Van Westen et al. 1997). The statistical index (SI) is calculated as follows: 
$W i j=\operatorname{In}\left(\frac{\text { DensClasij }}{\text { DensMap }}\right)=\operatorname{In}\left[\frac{\frac{N p i x(S i j)}{N \operatorname{pix}(N i j)}}{\frac{\sum_{j} N \operatorname{pix}(S i j)}{\sum_{j} N \operatorname{pix}(N i j)}}\right]$

Where $\mathrm{W}_{\mathrm{ij}}$ is the weight for class $\mathrm{j}$ within the triggering factor map $i$, DensClasij is density of landslides in class $j$ within the triggering factor map $i$, DensMap is the density of landslides in the entire map, $\mathrm{N}_{\text {pix }}\left(\mathrm{S}_{\mathrm{ij}}\right)$ is the number of pixels in class $j$ within the triggering factor map $i$ and $\mathrm{N}_{\text {pix }}\left(\mathrm{N}_{\mathrm{ij}}\right)$ is the number of pixels in class $j$ within the triggering factor map $i$. Thereafter, landslides hazard map was produced by using the following equation.

$$
\begin{array}{r}
\text { LHIsi }=W s i(\text { elevation })+W s i(\text { slope angle })+W s i(\text { slope carvature })+W s i(\text { rainfall }) \\
+ \text { Wsi }(\text { lithology })+W \text { si }(\text { soil texture })+W s i(\text { distance to roads }) \\
+ \text { Wsi }(\text { distance to rivers })+W s i(\text { Land Use })+W s i(N D V I)
\end{array}
$$

The obtained landslides hazard map was reclassified into five landslides hazard classes, namely: very low (2-3.18), low (3.18-3.77), moderate (3.77-4.5), high (4.5-5.7) and very high (5.7-8.8) based on the review of literature, experts' opinions and field observation.

\section{Results}

\subsection{Spatial distribution of landslides hazard in Rwanda}

The results on the spatial relationship between landslides hazard and its influencing factors, as estimated by the statistical index model (Table 1) indicated that for elevation, the higher and positive SI values of 1.82 and 0.42 were generated by the elevation ranges of $2194-2804 \mathrm{~m}$ and 1833-2194 m, respectively. For the relationship between landslides hazard and slope angles, the results in Table 1 showed that slope angles' range of $28-45^{\circ}$ generated a high SI value (0.36). The findings also revealed that the west-facing slope (0.64) and northwest-facing slope (0.49) have positive high SI values. For the rainfall, the results in Table 1 revealed that the range of $72-88$ $\mathrm{mm}$ and 109-152 $\mathrm{mm}$ have the highest positive values of SI; 0.84 and 0.78 , respectively. In addition, as illustrated in Table 1, the schist is the main lithological dominating class with highest positive SI value (0.71) and granite class represented the lowest negative SI value at -2.13 . The clay (0.37) and clay loam (0.12) soil texture classes revealed high SI value. Moreover, land use and land cover classes revealed that grassland possess the highest SI value (0.62) along with forest (0.68). The obtained relationship between NDVI and landslides hazard (Table 1) revealed 
that the NDVI range of $0.53-0.65$ has a highest and positive SI value of 0.89 . Furthermore, the distance to rivers mainly, the ranges of $0-150 \mathrm{~m}$ and 150-300 $\mathrm{m}$ have high SI values: 0.59 and 0.04, respectively. Finally, the results in Table 1 showed that for the distance to roads, the range of 250-500 $\mathrm{m}$ possess high positive SI value of 0.01 . Hence, the closer to roads and rivers, the greater is the landslide occurrence probability and hazard exposure.

Table 1 Spatial relationship between landslides hazard and triggering factors by SI model

\begin{tabular}{|c|c|c|c|c|c|c|}
\hline Factors & Classes & $\begin{array}{l}\text { Class } \\
\text { domain }(\%)\end{array}$ & $\begin{array}{l}\text { No.of } \\
\text { landslides }\end{array}$ & $\begin{array}{l}\text { Landslides } \\
\text { density (\%) }\end{array}$ & $\begin{array}{l}\text { landslides } \\
\text { pixels }\end{array}$ & $\mathrm{SI}$ \\
\hline \multirow[t]{5}{*}{ Elevation } & $2804-4486$ & 0.7 & 2 & 2.09 & 3036 & 0.32 \\
\hline & 2194-2804 & 8.8 & 192 & 63.3 & 3499 & 1.82 \\
\hline & $1833-2194$ & 12 & 87 & 32.7 & 3168 & 0.42 \\
\hline & $1541-1833$ & 31.2 & 64 & 1.6 & 1596 & -0.67 \\
\hline & $915-1541$ & 22.3 & 21 & 0.31 & 1372 & -0.02 \\
\hline \multirow[t]{5}{*}{ Slope } & $>60$ & 0.2 & 1 & 1.1 & 3369 & -0.26 \\
\hline & $45-60$ & 49.4 & 202 & 59.7 & 4427 & 0.21 \\
\hline & $28-45$ & 19.4 & 98 & 24.9 & 3791 & 0.36 \\
\hline & $12-28$ & 16 & 54 & 12 & 2548 & 0.23 \\
\hline & $0-12$ & 26 & 11 & 2.3 & 1978 & -0.82 \\
\hline \multirow[t]{5}{*}{ Rainfall } & $109-152$ & 18.2 & 97 & 13 & 2614 & 0.78 \\
\hline & 88-109 & 10.2 & 69 & 17.3 & 3320 & 0.29 \\
\hline & $72-88$ & 7 & 144 & 64.8 & 2719 & 0.84 \\
\hline & $57-72$ & 62.3 & 22 & 3.6 & 2201 & 0.32 \\
\hline & $32-57$ & 2.3 & 9 & 1.3 & 1123 & 0.47 \\
\hline \multirow[t]{10}{*}{ Lithology } & Volcanic ash & 0.6 & 22 & 9.3 & 2408 & 0.74 \\
\hline & $\begin{array}{l}\text { Basic igneous } \\
\text { rock }\end{array}$ & 4.4 & 44 & 4 & 2647 & -1.21 \\
\hline & Schist & 89.02 & 196 & 74.2 & 4642 & 0.71 \\
\hline & Quartzite & 0.05 & 36 & 8.4 & 3496 & 0.29 \\
\hline & Granite & 0.03 & 19 & 2 & 2458 & -2.13 \\
\hline & Colluvial & 0.02 & 0 & 0 & 23 & -0.79 \\
\hline & Fluvial & 0.2 & 0 & 0 & 630 & -0.52 \\
\hline & Organic & 0.2 & 0 & 0 & 29 & 0.39 \\
\hline & Water & 4.9 & 0 & 0 & 0 & 0.04 \\
\hline & Basalt & 0.4 & 9 & 2.1 & 1325 & -0.46 \\
\hline \multirow[t]{5}{*}{ Soil texture } & Loamy & 0.9 & 9 & 18.4 & 2039 & -0.26 \\
\hline & $\begin{array}{l}\text { Sandy clay } \\
\text { loamy }\end{array}$ & 2.1 & 4 & 7.7 & 1651 & -1.24 \\
\hline & Clay loamy & 68 & 154 & 32 & 3419 & 0.12 \\
\hline & Sand clay & 0.6 & 0 & 0.6 & 1242 & 0 \\
\hline & Clay & 28.4 & 169 & 51.3 & 4984 & 0.37 \\
\hline \multirow[t]{5}{*}{$\begin{array}{l}\text { LULC } \\
\end{array}$} & Built-up land & 3.2 & 6 & 4.3 & 1237 & -1.29 \\
\hline & Cropland & 60.4 & 247 & 59.7 & 4828 & -1.13 \\
\hline & Grassland & 14.2 & 31 & 11.4 & 1101 & 0.62 \\
\hline & Forest & 16.1 & 52 & 24.6 & 1971 & 0.86 \\
\hline & Water Bodies & 6.1 & 0 & 0 & 1003 & -0.31 \\
\hline \multirow[t]{5}{*}{ NDVI } & $0.65-0.99$ & 19.6 & 63 & 26.5 & 2759 & -0.55 \\
\hline & $0.53-0.65$ & 42 & 31 & 9.1 & 1621 & 0.24 \\
\hline & $0.40-0.53$ & 33.8 & 157 & 36.9 & 3827 & 0.89 \\
\hline & $0.16-0.40$ & 4.4 & 23 & 8.2 & 1086 & -0.8 \\
\hline & $-0.2-0.16$ & 0.2 & 62 & 19.3 & 1083 & 0-19 \\
\hline \multirow{5}{*}{$\begin{array}{l}\text { Distance to } \\
\text { rivers }\end{array}$} & $650-800$ & 0.4 & 0 & 0 & 1011 & -0.67 \\
\hline & $450-600$ & 3.6 & 18 & 4 & 1023 & -0.89 \\
\hline & $300-450$ & 12 & 44 & 29 & 2109 & -0.01 \\
\hline & $150-300$ & 31 & 31 & 20 & 3262 & 0.04 \\
\hline & $0-150$ & 54 & 243 & 47 & 3807 & 0.59 \\
\hline \multirow{2}{*}{$\begin{array}{l}\text { Distance to } \\
\text { roads }\end{array}$} & $1,000-1,250$ & 4.2 & 8 & 0.7 & 1018 & -0.32 \\
\hline & $750-1,000$ & 8 & 52 & 2.1 & 1214 & -0.69 \\
\hline
\end{tabular}




\begin{tabular}{|c|c|c|c|c|c|c|}
\hline & $500-750$ & 16 & 31 & 16 & 2313 & -0.05 \\
\hline & $250-500$ & 28.2 & 58 & 33 & 2548 & 0.01 \\
\hline & $0-250$ & 43.6 & 187 & 48.2 & 3807 & -1.21 \\
\hline \multirow[t]{9}{*}{ Aspects } & Flat & 0.6 & 0 & 0 & 450 & -0.03 \\
\hline & Northeast & 8.3 & 4 & 4.9 & 1356 & -0.18 \\
\hline & East & 2.3 & 0 & 1.3 & 1719 & -0.08 \\
\hline & Southeast & 2 & 0 & 0.1 & 2008 & -0.46 \\
\hline & South & 10 & 26 & 10.3 & 2148 & 0.18 \\
\hline & Southwest & 13.3 & 38 & 17.6 & 2981 & 0.23 \\
\hline & West & 12.4 & 145 & 31.1 & 3198 & 0.64 \\
\hline & Northwest & 39.2 & 96 & 20.3 & 2349 & 0.49 \\
\hline & North & 11.2 & 27 & 12.4 & 2027 & 0.21 \\
\hline
\end{tabular}

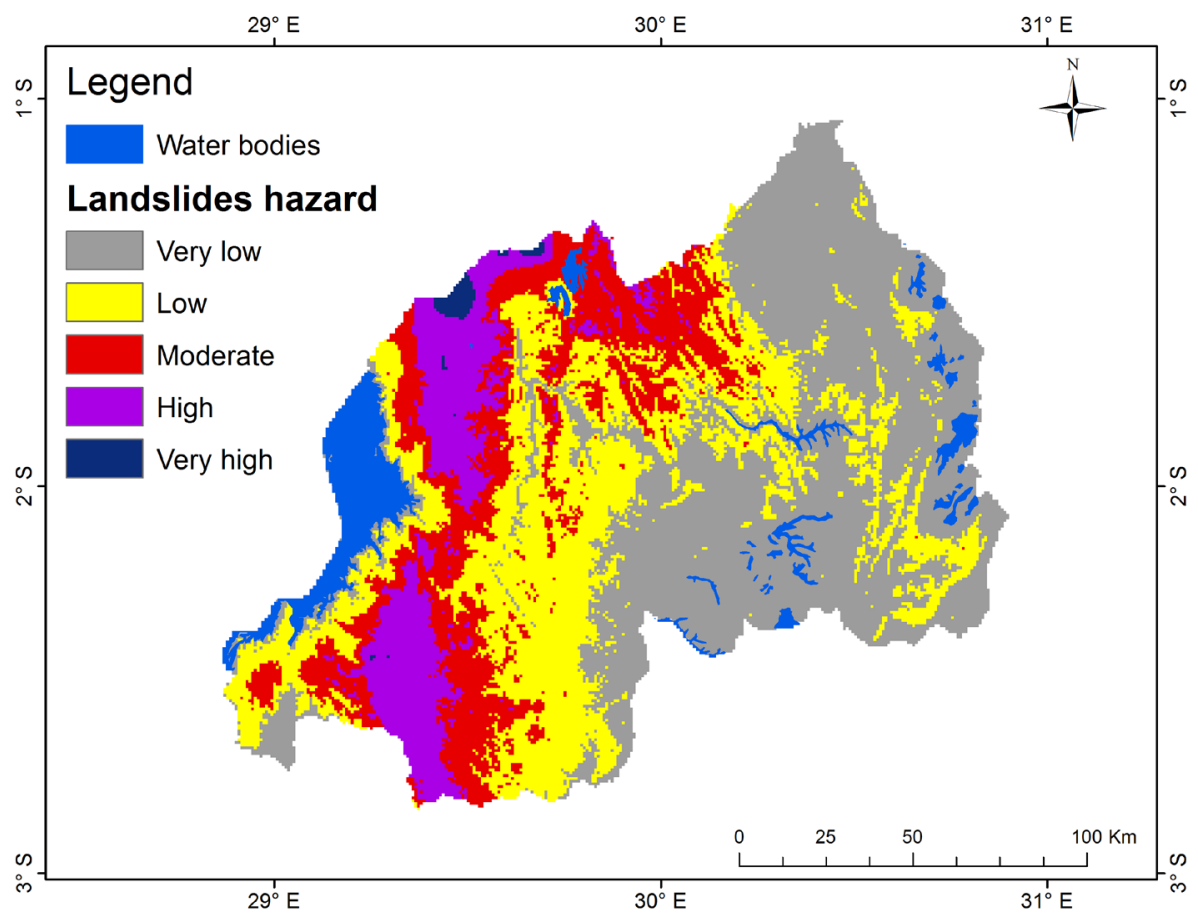

Figure 5. Spatial landslides hazard distribution over Rwanda

Table 2 Landslides hazard's population exposure per province in Rwanda

\begin{tabular}{lllc}
\hline & Hazard classes & Area $\mathbf{( \% )}$ & Population $\mathbf{( \% )}$ \\
\hline \multirow{5}{*}{ Southern } & Very low & 22.3 & 20.7 \\
& Low & 48.5 & 40.3 \\
& Moderate & 10.2 & 17.9 \\
& High & 19 & 21.1 \\
& Very high & 0 & 0 \\
\hline \multirow{5}{*}{ Northern } & Very low & 0.9 & 2.3 \\
& Low & 9.1 & 19.6 \\
& Moderate & 34 & 30.8 \\
& High & 52 & 36 \\
& Very high & 4 & 11.3 \\
\hline \multirow{5}{*}{ Western } & Very low & 1.2 & 3.9 \\
& Low & 12 & 20.2 \\
& Moderate & 30 & 31.6
\end{tabular}




\begin{tabular}{llcc} 
& High & 52.1 & 38.1 \\
& Very high & 4.7 & 6.2 \\
\hline \multirow{4}{*}{ Kigali } & Very low & 64.5 & 44.4 \\
& Low & 29.2 & 37.5 \\
& Moderate & 6.3 & 18.1 \\
& High & 0 & 0 \\
& Very high & 0 & 0 \\
\hline \multirow{4}{*}{ Eastern } & Very low & 67.3 & 58.6 \\
& Low & 32.4 & 38 \\
& Moderate & 0.38 & 3.4 \\
& High & 0 & 0 \\
\hline
\end{tabular}

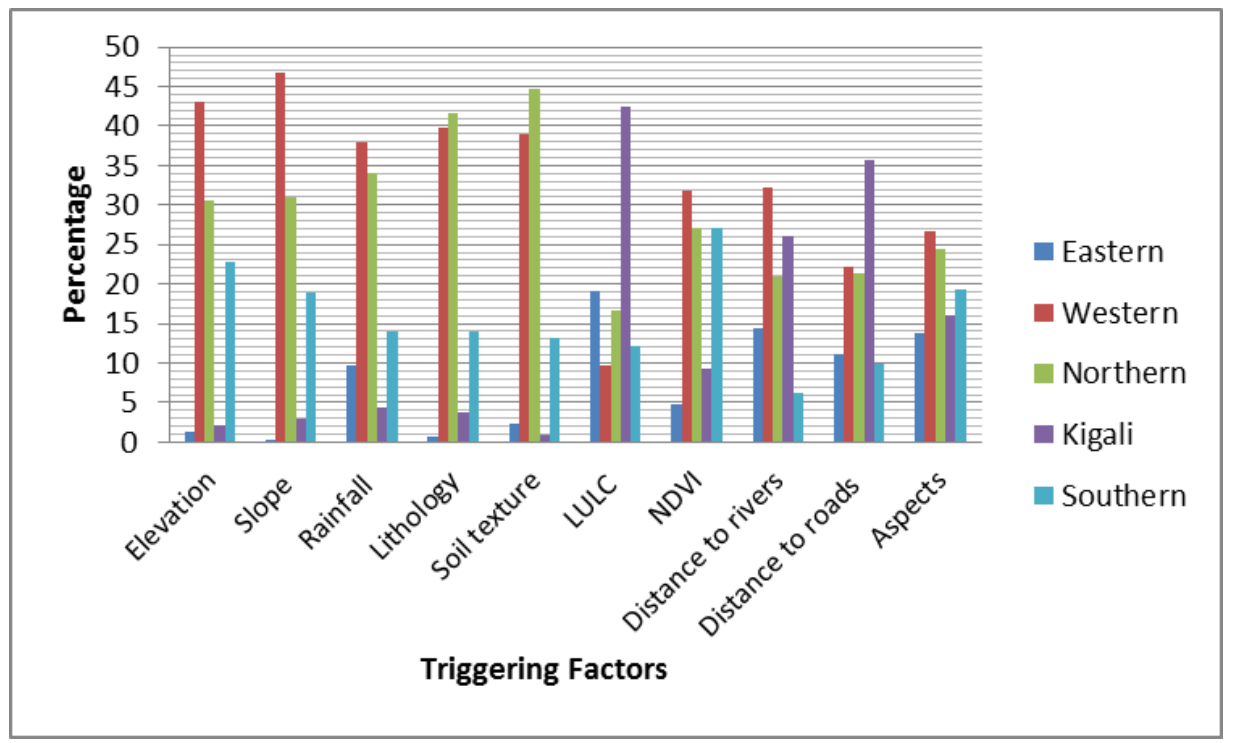

Figure 6. Estimated causal factor's contribution to landslides hazard per province

\subsection{Validation of landslides hazard map}

There are different ways of testing the validity of the model. The basic assumption underlying the goodness of fit test is that future landslides will occur in the same places as the past or existing movements in the study area. In case a hazard map coincides well with the inventory then maps are considered satisfactory (Guzzetti et al. 2012; Van Westen et al. 2008). For this study, landslides inventory databases (Fig.1 (b)) were used to test the goodness of the classified landslides hazard. Then, cumulative percentages of hazard classes corresponding to cumulative percentage of observed landslides were presented. The validation results in Fig.7 and Table 3 revealed that the statistical index model employed by this study generated good results because it confirmed that the constructed landslides hazard map coincided with past events. The results 
showed that a high number of past landslides (216 of 336) was observed within high landslides hazard zone which occupies $42.7 \%$ of the total landslides hazard in Rwanda.

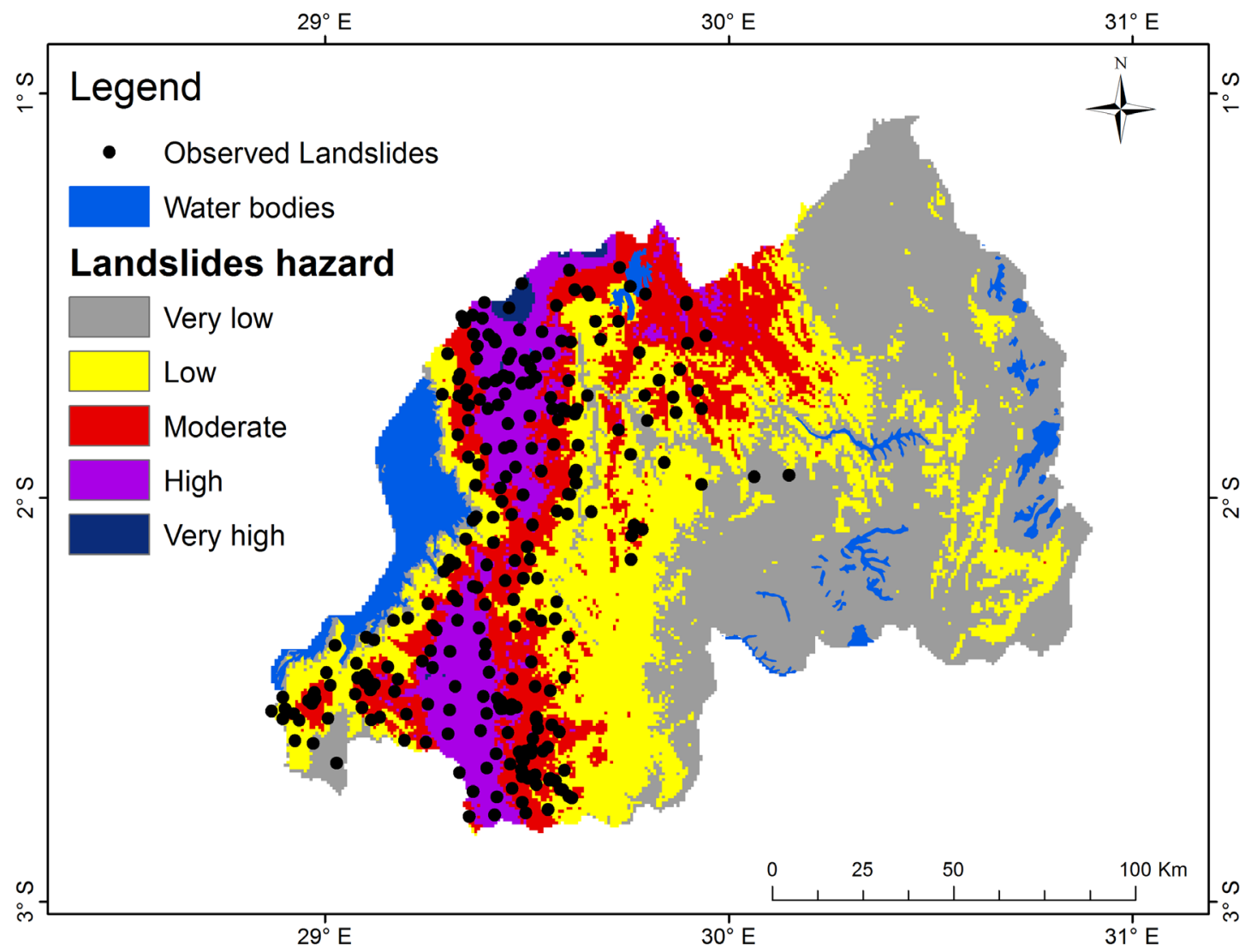

Figure 7. Prediction of future landslides occurrence likelihood based on previously observed events and its current spatial distribution in Rwanda

Table 3 Validation of the observed landslides per estimated hazard classes

\begin{tabular}{lccc}
\hline Hazard class & Hazard area (\%) & No. landslides & Landslides area (\%) \\
\hline Very low & 2.3 & 5 & 3.1 \\
Low & 12.6 & 43 & 21.9 \\
Moderate & 39.1 & 68 & 32.2 \\
High & 42.7 & 216 & 36.6 \\
Very high & 3.3 & 4 & 6.2 \\
Total & 100 & 336 & 100 \\
\hline
\end{tabular}

\section{Discussion}


Landslides hazard mapping is an important step in landslides investigation and landslides risk management. The process divides and ranks the land surface according to the degree of actual potential hazard from landslides (Di et al. 2017; Frodella et al. 2018; Ambrosi et al. 2018). Landslides inventories and databases are critical to support investigations of where and when landslides have happened and may occur in the future (Huang et al. 2013). In Rwanda, landslides severely impact on community and environmental safety. However, lack of precise knowledge of the key conditioning factors and historical database are among the challenges in hazard risk reduction (MIDIMAR 2014). The authors recognized this fact and employed ten landslides conditioning factors (Fig.2, 3 and 4) in order to produce a landslides hazard map (Fig.5), show the extent of each area's hazard exposure (Table 2) and the major triggering factors by hazard zone (Fig.6).

It is reported that within mountainous areas, high elevation and slope easily facilitate the runoff during intense rainfall then cause landslides (Petley 2012; Tian et al. 2017). This is congruent to Rwanda, dubbed: "a country of thousand hills" due to its mountainous landscape (MIDIMAR 2014). Accordingly, the results of this study (Fig.5) indicated that in Rwanda, moderate and high hazard zones record high precipitation, altitude and slope. Thus, for hazard risk reduction, it is good to expand areas under forest and promote the bench terraces and agroforestry practices along with rainfall harvest to minimize the runoff facilitated by its high elevation and slope. Hazard risk reduction requires a community-based approach through its direct participation in decision making, regular hazard-related meetings and timely information sharing, trainings and education delivery (Devkota et al. 2013; Tong et al. 2012). Such approaches enhance people's understanding on the types of hazard under record in their living areas, main causes and the kind of behaviour to adopt for the risk management. This can be applied in Rwanda with particular focus on the landslides hazard highly exposed areas (Fig. 5 and Table 2) in order to enable the residents to either settle in low hazard zones or ensure practices which minimize their landslides hazard exposure.

The occurrence of landslides does not only cause loss of human life, but also destroys natural habitat and causes species extinction, and destruction of other ecological services and natural heritage (Yalcin 2007; Kelman 2017; Capitani et al. 2013). In most cases, human activities are the key factors which exacerbate the impact of landslides. For example, the results in Fig.5 
classified Kigali city between low and moderate landslides hazard zones (Fig.5). This is due to the reason that the area records expanded built-ups, low vegetation cover, and is close to rivers and roads (Fig.3 and 4) which result from anthropogenic activities. This consequently, destroys infrastructures and causes water and soil pollution because during landslides occurrence, the exposed upper soil layers and other sediments are easily transported downslope then pollute the quality of water and soil as well (Nahayo et al. 2018). Hence, the prepared landslides hazard map (Fig.5) can indicate to the environmental and construction engineers the hazard level (from very low to very high). And this enhances the awareness on the safe places to install buildings and ways of minimizing the wastes that can be loaded into water during landslides, and the required water and soil pollution control and natural environment management policies.

The knowledge on the fact that past landslides occurrence expresses the future likelihood helps to predict and prepare for the future (Urlaub et al. 2013). As illustrated in Fig.7, landslides hazard map validated with previous landslides revealed that 284 of 336 landslides are localized within the moderate and high hazard zones which occupy $78.8 \%$ of the total landslides hazard. Thus, if landslides reoccur in Rwanda, people and their belongings, and natural resources located in moderate and high hazard zones may record greater losses and damages. For such areas, soft engineering, known as biotechnical slope stabilization technique, if applied, can help to stabilize the slope due to its advantage of combining both the use of vegetation and man-made structural elements (Popescu and Sasahara 2009). In addition, residents from high landslides hazard areas (Fig.5) can be transferred to safe hazard zones like eastern province (Table 2) with low values of triggering factors (Fig.6). This saves people's life and ensures proper land use and management.

\section{Conclusion}

The aim of this study was to produce a landslides hazard map of Rwanda. Authors applied GISbased statistical index model to analyze ten landslides causal factors. And the identified 336 points were used to produce a landslides inventory and validate the prepared landslides hazard map. The produced hazard map was divided into five hazard classes, i.e., very low, low, moderate, high and very high in order to differentiate landslides hazard, and enhance the knowledge on the hazard magnitude and major drivers across Rwanda. The results showed that the northern, southern and western provinces are highly exposed to landslides hazard due to high 
elevation, slope, rainfall and poor land management. The proposed method revealed reasonable results because 284 of 336 previous landslides events are observed within moderate and high landslides hazard classes which occupy 78.8 percent of total hazard. It is concluded that for reducing landslides hazard in Rwanda, it is good to envisage strong population growth control, and set up appropriate building and environmental/natural resources management strategies. These include not limited to (a) avoiding to emplace new constructions on steep slope or to stabilize the slope before starting new constructions, (b) directing surface and ground water away from landslides hazard prone areas, (c) minimizing the irrigation of surface soil, (d) removing mass from the top of slope so that its weight may not force the layer to slide, and (e) ensuring that bank rivers are protected to minimize runoff during landslides occurrence in order to enhance water quality and reduce soil loss. Further assessment on the effectiveness of the hazard risk reduction policies under execution is suggested.

\section{Acknowledgment}

The authors greatly thank the University of Chinese Academy of Sciences for this Scholarship awarded, and authors are grateful for the supports in data collection and analysis from the CAS Research Centre for Ecology and Environment of Central Asia.

\section{Conflict of Interests}

All authors declare no conflict of Interests

\section{References}

Alvioli, M., M. Melillo, F. Guzzetti, M. Rossi, E. Palazzi, J. von Hardenberg, M. T. Brunetti, and S. Peruccacci. 2018. Implications of climate change on landslide hazard in Central Italy. Science of the Total Environment 630:1528-1543.

Ambrosi, C., T. Strozzi, C. Scapozza, and U. Wegmüller. 2018. Landslide hazard assessment in the Himalayas (Nepal and Bhutan) based on Earth-Observation data. Engineering Geology 237:217228.

Banerjee, P., M. K. Ghose, and R. Pradhan. 2018. Analytic hierarchy process and information value method-based landslide susceptibility mapping and vehicle vulnerability assessment along a highway in Sikkim Himalaya. Arabian Journal of Geosciences 11 (7):139.

Bobrowsky, P., and L. Highland. 2013. The Landslide Handbook-a Guide to Understanding Landslides: A Landmark Publication for Landslide Education and Preparedness. In Landslides: Global Risk Preparedness: Springer, 75-84.

Cao, C., Q. Wang, J. Chen, Y. Ruan, L. Zheng, S. Song, and C. Niu. 2016. Landslide susceptibility mapping in vertical distribution law of precipitation area: Case of the Xulong Hydropower station Reservoir, Southwestern China. Water 8 (7):270. 
Capitani, M., A. Ribolini, and M. Bini. 2013. The slope aspect: A predisposing factor for landsliding? Comptes Rendus Geoscience 345 (11-12):427-438.

Devkota, K. C., A. D. Regmi, H. R. Pourghasemi, K. Yoshida, B. Pradhan, I. C. Ryu, M. R. Dhital, and O. F. Althuwaynee. 2013. Landslide susceptibility mapping using certainty factor, index of entropy and logistic regression models in GIS and their comparison at Mugling-Narayanghat road section in Nepal Himalaya. Natural hazards 65 (1):135-165.

Di, B., C. A. Stamatopoulos, M. Dandoulaki, E. Stavrogiannopoulou, M. Zhang, and P. Bampina. 2017. A method predicting the earthquake-induced landslide risk by back analyses of past landslides and its application in the region of the Wenchuan 12/5/2008 earthquake. Natural hazards 85 (2):903-927.

Dou, J., D. T. Bui, A. P. Yunus, K. Jia, X. Song, I. Revhaug, H. Xia, and Z. Zhu. 2015. Optimization of causative factors for landslide susceptibility evaluation using remote sensing and GIS data in parts of Niigata, Japan. PLoS ONE 10 (7):e0133262.

Fan, W., X.-s. Wei, Y.-b. Cao, and B. Zheng. 2017. Landslide susceptibility assessment using the certainty factor and analytic hierarchy process. Journal of Mountain Science 14 (5):906-925.

Fan, X., W. Zhan, X. Dong, C. van Westen, Q. Xu, L. Dai, Q. Yang, R. Huang, and H.-B. Havenith. 2018. Analyzing successive landslide dam formation by different triggering mechanisms: The case of the Tangjiawan landslide, Sichuan, China. Engineering Geology 243:128-144.

Fey, C., M. Rutzinger, V. Wichmann, C. Prager, M. Bremer, and C. Zangerl. 2015. Deriving 3D displacement vectors from multi-temporal airborne laser scanning data for landslide activity analyses. GIScience \& Remote Sensing 52 (4):437-461.

Frodella, W., A. Ciampalini, F. Bardi, T. Salvatici, F. Di Traglia, G. Basile, and N. Casagli. 2018. A method for assessing and managing landslide residual hazard in urban areas. Landslides 15 (2):183-197.

Guzzetti, F., A. C. Mondini, M. Cardinali, F. Fiorucci, M. Santangelo, and K.-T. Chang. 2012. Landslide inventory maps: New tools for an old problem. Earth-Science Reviews 112 (1-2):42-66.

Hong, H., H. R. Pourghasemi, and Z. S. Pourtaghi. 2016. Landslide susceptibility assessment in Lianhua County (China): a comparison between a random forest data mining technique and bivariate and multivariate statistical models. Geomorphology 259:105-118.

Huang, J., A. Lyamin, D. Griffiths, K. Krabbenhoft, and S. Sloan. 2013. Quantitative risk assessment of landslide by limit analysis and random fields. Computers and Geotechnics 53:60-67.

Ibrahim, Y. Z., H. Balzter, J. Kaduk, and C. J. Tucker. 2015. Land degradation assessment using residual trend analysis of GIMMS NDVI3g, soil moisture and rainfall in Sub-Saharan West Africa from 1982 to 2012. Remote Sensing 7 (5):5471-5494.

Jaafari, A., A. Najafi, J. Rezaeian, A. Sattarian, and I. Ghajar. 2015. Planning road networks in landslideprone areas: a case study from the northern forests of Iran. Land Use Policy 47:198-208.

Kannan, M., E. Saranathan, and R. Anabalagan. 2013. Landslide vulnerability mapping using frequency ratio model: a geospatial approach in Bodi-Bodimettu Ghat section, Theni district, Tamil Nadu, India. Arabian Journal of Geosciences 6 (8):2901-2913.

Kazakis, N., I. Kougias, and T. Patsialis. 2015. Assessment of flood hazard areas at a regional scale using an index-based approach and Analytical Hierarchy Process: Application in Rhodope-Evros region, Greece. Science of the Total Environment 538:555-563.

Kelman, I. 2017. Linking disaster risk reduction, climate change, and the sustainable development goals. Disaster Prevention and Management: An International Journal 26 (3):254-258.

Kim, D., S. Im, S. H. Lee, Y. Hong, and K.-S. Cha. 2010. Predicting the rainfall-triggered landslides in a forested mountain region using TRIGRS model. Journal of Mountain Science 7 (1):83-91.

Kim, H. G., D. K. Lee, C. Park, Y. Ahn, S.-H. Kil, S. Sung, and G. S. Biging. 2018. Estimating landslide susceptibility areas considering the uncertainty inherent in modeling methods. Stochastic environmental research and risk assessment 32 (11):2987-3019.

Lee, S., J.-S. Won, S. W. Jeon, I. Park, and M. J. Lee. 2015. Spatial landslide hazard prediction using rainfall probability and a logistic regression model. Mathematical Geosciences 47 (5):565-589. 
Lei, Y., Y. Yue, H. Zhou, and W. Yin. 2014. Rethinking the relationships of vulnerability, resilience, and adaptation from a disaster risk perspective. Natural hazards 70 (1):609-627.

Lian, C., Z. Zeng, W. Yao, and H. Tang. 2014. Extreme learning machine for the displacement prediction of landslide under rainfall and reservoir level. Stochastic environmental research and risk assessment 28 (8):1957-1972.

Mertens, K., L. Jacobs, J. Maes, J. Poesen, M. Kervyn, and L. Vranken. 2018. Disaster risk reduction among households exposed to landslide hazard: A crucial role for self-efficacy? Land Use Policy 75:77-91.

Micheletti, N., L. Foresti, S. Robert, M. Leuenberger, A. Pedrazzini, M. Jaboyedoff, and M. Kanevski. 2014. Machine learning feature selection methods for landslide susceptibility mapping. Mathematical Geosciences 46 (1):33-57.

MIDIMAR. 2014. National Contingency for Flood and Landslides, Ministry of Disaster Management and Refugees, (MIDIMAR), Kigali- Rwanda.47.

Nahayo, L., C. Mupenzi, E. Kalisa, V. Mukanyandwi, A. Gasirabo, and E. Hakorimana. 2018. Seasonal Drinking Water Quality Monitoring for the Community Wellbeing in the Eastern Rwanda. Journal of Environment Protection and Sustainable Development 4 (1):1-6.

Nahayo, L., C. Mupenzi, A. Kayiranga, F. Karamage, F. Ndayisaba, E. M. Nyesheja, and L. Li. 2017. Early alert and community involvement: approach for disaster risk reduction in Rwanda. Natural Hazards 86 (2):505-517.

Naidu, S., K. Sajinkumar, T. Oommen, V. Anuja, R. A. Samuel, and C. Muraleedharan. 2017. Early warning system for shallow landslides using rainfall threshold and slope stability analysis. Geoscience Frontiers.

Nduwayezu, E., M. Jaboyedoff, P.-C. Bugnon, J.-B. Nsengiyumva, P. Horton, and M.-H. Derron. 2015. Meteorological Hazard Assessment and Risk Mitigation in Rwanda. Paper read at EGU General Assembly Conference Abstracts.

Nichol, J. E., A. Shaker, and M.-S. Wong. 2006. Application of high-resolution stereo satellite images to detailed landslide hazard assessment. Geomorphology 76 (1-2):68-75.

Nsengiyumva, J. B., G. Luo, L. Nahayo, X. Huang, and P. Cai. 2018. Landslide susceptibility assessment using spatial multi-criteria evaluation model in Rwanda. International journal of environmental research and public health 15 (2):243.

Petley, D. 2012. Landslides and engineered slopes: protecting society through improved understanding. Landslides and engineered slopes 1:3-13.

Piller, A. N. 2016. Precipitation Intensity Required for Landslide Initiation in Rwanda.

Popescu, M. E., and K. Sasahara. 2009. Engineering measures for landslide disaster mitigation. In Landslides-Disaster Risk Reduction: Springer, 609-631.

RCMRD. 2018. Regional Center for Mapping of Resources for Development (RCMRD). Land Cover Viewer: Eastern and Southern Africa. Available online: http://apps.rcmrd.org/landcoverviewer/ (accessed on 12 March 2018).

Reis, S., R. Nişanci, and T. Yomralioğlu. 2009. Designing and developing a province-based spatial database for the analysis of potential environmental issues in Trabzon, Turkey. Environmental engineering science 26 (1):123-130.

Riedel, P. S., A. R. Gomes, M. V. Ferreira, E. S. Sampaio Lopes, and J. R. Sturaro. 2010. Identification of Landslide Scars in the Region of the Serra do Mar, São Paulo State, Brazil, Using Digital Image Processing and Spatial Analysis Tools. GIScience \& Remote Sensing 47 (4):498-513.

RMA. 2018. Rwanda Meteorological Agency, Meteo Rwanda Map Room, Climate Data Library, Available at: http://www.

meteorwanda.gov.rw/maproom, Accessed on April 05, 2018.

Rushemuka, P. N., L. Bock, and J. G. Mowo. 2014. Soil science and agricultural development in Rwanda: state of the art. A review. BASE. 
Sharma, L., N. Patel, M. Ghose, and P. Debnath. 2014. Application of frequency ratio and likelihood ratio model for geo-spatial modelling of landslide hazard vulnerability assessment and zonation: a case study from the Sikkim Himalayas in India. Geocarto International 29 (2):128-146.

Shi-Biao, B., W. Jian, L. Guo-Nian, Z. Ping-Gen, H. Sheng-Shan, and X. Su-Ning. 2009. GIS-based and data-driven bivariate landslide-susceptibility mapping in the Three Gorges area, China. Pedosphere 19 (1):14-20.

Tian, Y., C. Xu, J. Chen, and H. Hong. 2017. Spatial distribution and susceptibility analyses of preearthquake and coseismic landslides related to the Ms 6.5 earthquake of 2014 in Ludian, Yunan, China. Geocarto International 32 (9):978-989.

Tong, T. M. T., R. Shaw, and Y. Takeuchi. 2012. Climate disaster resilience of the education sector in Thua Thien Hue Province, Central Vietnam. Natural hazards 63 (2):685-709.

Urlaub, M., P. J. Talling, and D. G. Masson. 2013. Timing and frequency of large submarine landslides: implications for understanding triggers and future geohazard. Quaternary Science Reviews 72:6382.

USGS. 2018. United States Geological Survey, Science for a Changing World, avaialable at:https://earthexplorer.usgs.gov/, accessed on July 2017.

Van Westen, C. J., E. Castellanos, and S. L. Kuriakose. 2008. Spatial data for landslide susceptibility, hazard, and vulnerability assessment: an overview. Engineering Geology 102 (3-4):112-131.

Van Westen, C. J., N. Rengers, M. Terlien, and R. Soeters. 1997. Prediction of the occurrence of slope instability phenomenal through GIS-based hazard zonation. Geologische Rundschau 86 (2):404414.

Xu, S., Q. Zhao, Y. Liu, S. Ding, and M. Qin. 2018. Sensitivity and Applicability of Landscape Leakiness Index in Determining Soil and Water Conservation Function of a Subtropical Riparian Vegetation Buffer Zone. Environmental engineering science.

Yalcin, A. 2007. Environmental impacts of landslides: a case study from East Black Sea region, Turkey. Environmental engineering science 24 (6):821-833.

Yiping, W., C. Cong, H. Gaofeng, and Z. Qiuxia. 2014. Landslide stability analysis based on randomfuzzy reliability: taking Liangshuijing landslide as a case. Stochastic environmental research and risk assessment 28 (7):1723-1732.

Zhu, Z., J. Xie, J. Zhang, H. Liang, Y. Qiu, Z. Xia, Q. Ling, J. Lin, and H. Zhou. 2007. Characteristics of geological hazards in South China coastal areas and impact on regional sustainable development. The International Journal of Sustainable Development \& World Ecology 14 (4):421-427. 